\title{
EVALUASI PENGGUNAAN JENIS SELTER BERBEDA TERHADAP RESPONS STRES DAN KINERJA PRODUKSI PENDEDERAN LOBSTER AIR TAWAR Cherax quadricarinatus DALAM SISTEM RESIRKULASI
}

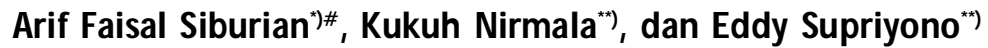 \\ *) Program Studi IImu Akuakultur, Fakultas Perikanan dan IImu Kelautan, Institut Pertanian Bogor \\ Jl. Agatis, Kampus Dramaga, Bogor, Jawa Barat 16680 \\ *) Departemen Budidaya Perairan, Fakultas Perikanan dan IImu Kelautan, Institut Pertanian Bogor \\ Jl. Agatis, Kampus Dramaga, Bogor, Jawa Barat 16680
}

(Naskah diterima: 31 Desember 2018; Revisi final: 19 Maret 2019; Disetujui publikasi: 20 Maret 2019)

\begin{abstract}
ABSTRAK
Sintasan yang rendah pada pembenihan lobster air tawar tidak terlepas dari karakteristik lobster air tawar yang teritorial pada areal yang terbatas, sering menunjukkan sifat agresif pada umur muda, dan memiliki perilaku kanibalisme. Tujuan dari penelitian ini adalah mengevaluasi pengaruh penggunaan selter yang berbeda terhadap respons stres dan kinerja produksi sehingga dapat menentukan jenis selter yang tepat untuk pendederan lobster air tawar Cherax quadricarinatus. Penelitian ini menggunakan rancangan acak lengkap dengan empat perlakuan dan tiga ulangan. Perlakuan pada penelitian ini adalah penggunaan selter yang berbeda yakni pipa PVC, roster (ventilasi blok), tali rafia, dan tanpa selter (kontrol). Benih lobster air tawar yang digunakan memiliki bobot rata-rata awal berkisar antara 0,60 $0,09-0,64 \pm 0,02 \mathrm{~g}$ dan panjang total rata-rata awal berkisar antara $2,55 \pm 0,06-2,61 \pm 0,03 \mathrm{~cm}$ yang dipelihara dalam sistem resirkulasi selama 60 hari. Perlakuan dengan penggunaan selter ataupun tanpa selter (kontrol) tidak memberikan pengaruh signifikan $(P>0,05)$ terhadap respons stres, namun memberikan pengaruh signifikan $(\mathrm{P}<0,05)$ pada kinerja produksi benih lobster air tawar di akhir penelitian. Perlakuan terbaik pada penelitian ini adalah penggunaan selter tali rafia dengan kadar glukosa sebesar 101,00 $\pm 17,35 \mathrm{mg} / \mathrm{dL}$; protein total

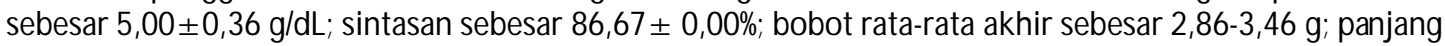
total rata-rata akhir sebesar 4,47-5,08 cm; laju pertumbuhan bobot spesifik sebesar 2,92 $\pm 0,21 \%$ /hari; laju pertumbuhan panjang spesifik sebesar $1,15 \pm 0,08 \%$ /hari; rasio konversi pakan sebesar $2,97 \pm 0,05$; dan biomassa total sebesar $45,02 \pm 1,10 \mathrm{~g}$. Penggunaan tali rafia sebagai selter menjadi perlakuan yang terbaik karena kemampuan tali rafia memisahkan banyak individu sehingga dapat mengurangi kanibalisme dengan cara meminimalkan kontak antarbenih lobster air tawar.
\end{abstract}

KATA KUNCl: Cherax quadricarinatus; kanibalisme; kinerja produksi; respons stres; selter

ABSTRACT: Evaluation of use different types of shelter on stress response and performance production of freshwater crayfish Cherax quadricarinatus in recirculation system. By: Arif Faisal Siburian, Kukuh Nirmala, and Eddy Supriyono

The low survival rate in seed production of freshwater crayfish is mainly caused by the territorial behavior of freshwater crayfish which leads to aggressiveness and cannibalism behavior even at a young age. This research aimed to determine the effect of using different nursery shelters on stress responses and production performance of freshwater crayfish Cherax quadricarinatus. This research used a completely randomized design consisted of four treatments, each with triplicate. The treatments used were different shelters made from PVC pipes, ventilation blocks, raffia ropes, and no shelters as controls. The freshwater crayfish seeds had initial weights ranged from $0.60 \pm 0.09-0.64 \pm 0.02 \mathrm{~g}$, and total length ranged from 2.55 $\pm 0.06-2.61 \pm 0.03$ and reared in a recirculation system for 60 days. The results of the research showed that all treatments including controls did not have a significant effect $(P>0.05)$ on stress responses but had a significant effect $(P<0.05)$ on the production performance of freshwater crayfish seed at the end of this

\footnotetext{
\# Korespondensi: Program Studi IImu Akuakultur, Fakultas

Perikanan dan IImu Kelautan, Institut Pertanian Bogor.

Jl. Agatis, Kampus Dramaga, Bogor, Jawa Barat 16680,

Indonesia.

Tel. + 622518622909

E-mail: ariffaisalsiburian@gmail.com
} 
research. The seeds reared with raffia ropes shelter had the best production performance indicated by its glucose level of $101.00 \pm 17.35 \mathrm{mg} \mathrm{dL1}$, total protein level of $5.00 \pm 0.36 \mathrm{~g} \mathrm{dL1}$, survival rate of $86.67 \pm 0.00 \%$ final average weight of $3.46 \pm 0.08 \mathrm{~g}$, final average total length of $5.08 \pm 0.12 \mathrm{~cm}$, specific weight growth rate of $2.92 \pm 0.21 \%$ per day, specific length growth rate of $1.15 \pm 0.08 \%$ per day, feed conversion ratio of $2.97 \pm 0.05$, and total biomass of $45.02 \pm 1.10 \mathrm{~g}$. The use of raffia ropes is considered as the best shelter for freshwater crayfish seed as it provides more space to separate individual seeds which can reduce cannibalism behaviour due to minimum contact between individual seeds.

\section{KEYWORDS: Cherax quadricarinatus; cannibalism; production performance; stress response; shelter}

\section{PENDAHULUAN}

Lobster air tawar yang cukup dikenal adalah dari genus Cherax (Olszewski, 1980). Salah satu spesies lobster air tawar yang termasuk dalam genus Cherax adalah Cherax quadricarinatusatau biasa dikenal dengan redclaw (capit merah) yang berasal dari Benua Australia bagian Utara (Queensland dan Northern Territory) dan Papua New Guinea bagian Selatan (Munasinghe et al., 2004). Budidaya lobster air tawar sangat potensial untuk terus dikembangkan karena memiliki toleransi yang tinggi terhadap variasi kualitas lingkungan, siklus reproduksi yang sederhana, tingkat pertumbuhan tinggi, masalah penyakit relatif sedikit, serta warna dan bentuk badan yang menarik sehingga membuat lobster air tawar cocok untuk industri akuakultur yang menjanjikan, baik pasar konsumsi maupun hias (Jones et al., 2000).

Indonesia sebagai salah satu negara produsen lobster air tawar (FAO, 2016) memerlukan upaya peningkatan produksi melalui pembenihan. Kegiatan pembenihan lobster air tawar seringkali terkendala rendahnya sintasan dan teknik pemeliharaan benih yang masih sulit untuk dipahami (Parnes $\&$ Sagi, 2002). Secara alami lobster air tawar memiliki sifat kanibalisme dan dalam pertumbuhannya, benih lobster air tawar sering mengalami moulting (pergantian kulit) yang menyebabkan badan lobster air tawar tersebut dalam keadaan yang lemah sehingga mudah dimakan oleh lobster air tawar lain yang sehat (Jones, 1995). Ukuran benih yang tidak seragam dalam budidaya dapat menyebabkan potensi terjadinya kanibalisme hingga menimbulkan kematian (GarcíaUlloa et al., 2012). Salah satu cara untuk mengatasi permasalahan tersebut adalah perlu dilakukan kegiatan pendederan benih lobster air tawar sebelum dilakukan pembesaran.

Pendederan merupakan tahap pelepasan atau penyebaran benih ke tempat pembesaran sementara. Pendederan menjadi tahap yang penting karena pada fase ini terdapat proses penyeleksian benih dengan ukuran yang seragam. Pendederan benih lobster air tawar dapat dilakukan secara indoor untuk memudahkan mengontrol dan memantau pemeliharaan benih lobster air tawar (Parnes \& Sagi, 2002). Pendederan benih lobster air tawar secara indoor dapat dilakukan dengan menggunakan sistem resirkulasi yang memungkinkan adanya efisiensi penggunaan air dan pengelolaan kualitas air sehingga dapat menciptakan kondisi lingkungan yang terkontrol (Timmons \& Losordo, 1994). Penelitian RodriguezCanto et al. (2002) menjelaskan bahwa pemeliharaan lobster air tawar pada sistem resirkulasi dapat meningkatkan sintasan lobster air tawar (25\%50\%lebih tinggi dari kolam tanah) dan memberikan pertumbuhan yang lebih seragam.

Sintasan yang rendah pada pembenihan lobster air tawar juga tidak terlepas dari karakteristik lobster air tawar yang termasuk hewan teritorial pada areal yang terbatas (Lukito \& Prayugo, 2007). Lobster air tawar pada umur muda sering menunjukkan sifat agresif yang tinggi dengan perilaku kanibalisme (Masser \& Rouse, 1997); sehingga lobster air tawar menyukai habitat yang memiliki banyak celah, serta rongga untuk dijelajahi dan menyembunyikan diri sebagai tempat perlindungan selama moulting untuk menghindari predasi dan kanibalisme (Kurniasih, 2008). Upaya yang telah dilakukan untuk mengurangi tingginya tingkat kanibalisme adalah dengan penggunaan selter sebagai tempat persembunyian buatan lobster air tawar.

Pengaruh penggunaan selter dalam beberapa penelitian menunjukkan hasil yang positif. Karplus et al. (1995) mengatakan bahwa pemeliharaan benih lobster air tawar Cherax quadricarinatus dengan menggunakan jenis selter berbeda yakni pipa PVC dan batu kerikil memberikan sintasan yang lebih tinggi dibandingkan pemeliharaan benih tanpa menggunakan selter (kontrol). Verhoef \& Austin (1999) yang melakukan penelitian penggunaan selter yang berbeda pada pemeliharaan benih lobster air tawar Cherax destructor yakni kantong bawang, batu scoria, dan pipa karet juga menghasilkan sintasan tertinggi dibandingkan pemeliharaan benih tanpa selter (kontrol). Penelitian lain yang menunjukkan peningkatan sintasan benih lobster air tawar Cherax quadricarinatus dengan pemeliharaan benih 
menggunakan selter yang berbeda telah dilakukan oleh Jones \& Ruscoe (2001), di mana selter bundel jala memberikan sintasan tertinggi dibanding penggunaan selter ban mobil, elevated sheets, flat sheets, pipa spiral, dan tanpa selter (kontrol).

Pemilihan selter yang tepat dapat mencegah terjadinya stres pada benih lobster air tawar. Faktor stres akibat pemilihan selter yang tidak nyaman saat pemeliharaan benih dapat menghambat laju pertumbuhan maupun sintasan benih lobster air tawar. Stres merupakan suatu kondisi ketidaknyamanan nonspesifik yang mengakibatkan dampak yang merugikan antara lain: penurunan imunitas, kegagalan reproduksi, penurunan bo bot, hingga kepada kematian (Woodward \& Strange, 1987). Pada pendederan lobster pasir (Panulirus homarus), penggunaan selter menghasilkan respons stres yang lebih rendah dibandingkan kontrol di mana selter pipa PVC merupakan selter yang terbaik, karena mampu menekan tingkat tres, serta menghasilkan pertumbuhan dan sintasan yang lebih baik dibanding perlakuan lainnya (Adiyana et al., 2014).

Penelitian yang mengevaluasi penggunaan selter terhadap respons stres pada benih lobster air tawar khususnya Cherax quadricarinatus belum banyak dilakukan, sehingga perlu dilakukan kajian lebih lanjut. Pengaruh penggunaan selter dalam budidaya lobster air tawar diharapkan dapat menjadi solusi dalam mengatasi kanibalisme dan mampu menekan tingkat stres, sehingga dapat menghasilkan kinerja produksi yang optimal.

\section{BAHAN DAN METODE}

\section{Waktu dan Tempat Penelitian}

Penelitian ini dilaksanakan dari bulan November 2017 sampai Maret 2018. Pemeliharaan benih lobster air tawar dilakukan di Laboratorium Kolam Percobaan Babakan, Fakultas Perikanan dan Ilmu Kelautan (FPIK), Institut Pertanian Bogor (IPB). Analisis respons stres dilaksanakan di Laboratorium Patologi, Pusat Studi Satwa Primata (PSSP), IPB. Analisis kualitas air dilaksanakan di Laboratorium Lingkungan Akuakultur, Departemen Budidaya Perairan, FPIK, IPB.

\section{Rancangan Penelitian}

Penelitian ini dilakukan dengan metode eksperimental. Rancangan perco baan yang digunakan adalah rancangan acak lengkap (RAL) yang terdiri atas empat perlakuan dan tiga ulangan. Tipe dan deskripsi perlakuan yang digunakan dalam penelitian ini dapat dilihat pada Tabel 1 .

\section{Prosedur Penelitian}

Pemeliharaan benih lobster air tawar dilakukan secara indoor dengan sistem resirkulasi menggunakan 12 wadah pemeliharaan berupa bak plastik berukuran $50 \mathrm{~cm} \times 30 \mathrm{~cm} \times 30 \mathrm{~cm}$ dan empat tandon berupa bak plastik berukuran $100 \mathrm{~cm} \times 80 \mathrm{~cm} \times 80 \mathrm{~cm}$ yang di dalamnya telah dilengkapi dengan filter dan pompa celup. Air pemeliharaan dari wadah pemeliharaan mengalir ke tandon melalui pipa yang selanjutnya mengalir ke dalam filter fisik (kapas dakron dan pasir silika), filter kimia (zeolit), dan filter biologi (bioball).

Benih lobster air tawar yang digunakan berumur satu bulan dengan bobot rata-rata $0,60 \pm 0,09-0,64$ $\pm 0,02 \mathrm{~g}$ dan panjang total rata-rata berkisar antara $2,55 \pm 0,06-2,61 \pm 0,03 \mathrm{~cm}$. Benih lobster air tawar sebelum perlakuan diaklimatisasi selama tujuh hari. Wadah aklimatisasi yang digunakan berupa bak plastik berukuran $100 \mathrm{~cm}$ x $80 \mathrm{~cm} \times 80 \mathrm{~cm}$. Setelah aklimatisasi, benih lobster air tawar disortir dan ditimbang agar bobotnya seragam. Padat tebar yang digunakan adalah sebanyak 15 ekor tiap wadah pemeliharaan.

Pemeliharaan benih lobster air tawar dilaksanakan selama 60 hari. Pakan yang digunakan merupakan pakan udang komersial dengan kadar protein $40 \%$ Pemberian pakan pada benih lobster air tawar dilakukan secara at restricted dengan frekuensi empat kali sehari yaitu pada pukul 08.00, 13.00, 18.00, dan 23.00 WIB. Pakan ditebar secara merata dan diberikan sebanyak 5\%dari bobot benih lobster air tawar.

\section{Parameter Penelitian}

Parameter penelitian yang diamati dan diukur dalam penelitian ini antara lain kualitas air, respons stres, dan kinerja produksi. Kualitas air yang diamati meliputi suhu, pH, dan oksigen terlarut yang diukur setiap hari selama penelitian, serta kesadahan, alkalinitas, total ammonia nitrogen (TAN), nitrit, dan nitrat yang diukur setiap 10 hari selama penelitian. Respons stres yang diamati meliputi glukosa dan protein total yang diukur pada awal dan akhir penelitian. Sedangkan kinerja produksi yang diamati meliputi sintasan, pertumbuhan bobot, pertumbuhan panjang total, laju pertumbuhan bobot spesifik, laju pertumbuhan panjang spesifik, rasio konversi pakan, dan biomassa total.

\section{Analisis Statistik}

Data yang diperoleh ditabulasi menggunakan Ms. Excel 2016 dan dianalisis dengan menggunakan program SPSS 24.0. Data dianalisis dengan analisis ragam pada selang kepercayaan 95\% untuk menentukan apakah perlakuan memberikan pengaruh signifikan 
Tabel 1. Deskripsi perlakuan yang digunakan

Table 1. Description of treatment used

\begin{tabular}{|c|c|c|}
\hline $\begin{array}{l}\text { Perlakuan } \\
\text { Treatments }\end{array}$ & $\begin{array}{l}\text { Jenis selter } \\
\text { Types of shelter }\end{array}$ & Deskripsi (Description) \\
\hline K & $\begin{array}{l}\text { Tanpa selter } \\
\text { Without shelter }\end{array}$ & Kontrol (Control) \\
\hline A & $\begin{array}{l}\text { Pipa PVC } \\
\text { PVC pipe }\end{array}$ & $\begin{array}{c}\text { Selter yang tersusun dari potongan pipa PVC dengan satu sisi tertutup (semi-closed). } \\
\text { Potongan pipa PVC tersebut memiliki diameter luar } 1,5 \text { inci dan panjang } 8 \mathrm{~cm} \text { dengan } \\
\text { jumlah yang sesuai dengan jumlah lobster air tawar yang dipelihara (1:1) } \\
\text { Shelter made from PVC pipe pieces with one was sealed (semi-closed). PVC pipes have an outer } \\
\text { diameter of } 1.5 \text { inches and a length of } 8 \mathrm{~cm} \text { with the number equal to the number of freshwater } \\
\text { crayfish reared (1:1) }\end{array}$ \\
\hline B & $\begin{array}{c}\text { Roster } \\
\text { Ventilation block }\end{array}$ & $\begin{array}{l}\text { Selter berupa roster (ventilasi blok) dengan satu sisi tertutup (semi-closed). Roster } \\
\text { tersebut memiliki pola lubang angin berbentuk kubus dengan dimensi } 3,5 \mathrm{~cm} \times 3,5 \mathrm{~cm} \\
\text { x } 8 \mathrm{~cm} \text { yang terbuat dari beton dengan jumlah lubang angin sesuai dengan jumlah } \\
\text { lobster air tawar yang dipelihara (1:1) } \\
\text { Shelter made from ventilation block with one side closed (semi-closed). Ventilation block have a } \\
\text { cube pattern with } 3.5 \mathrm{~cm} \times 3.5 \mathrm{~cm} \times 8 \mathrm{~cm} \text { dimension made of concrete with the number equal } \\
\text { to the number of freshwater crayfish reared (1:1) }\end{array}$ \\
\hline C & $\begin{array}{c}\text { Tali rafia } \\
\text { Raffia ropes }\end{array}$ & $\begin{array}{l}\text { Selter berupa potongan-potongan tali rafia dengan panjang } 20 \mathrm{~cm} \text { dan lebar } 0,5 \mathrm{~cm} \\
\text { sebanyak } 1.000 \text { helai yang digabungkan pada salah satu ujung dan ujung yang lain } \\
\text { dibiarkan memanjang dan menyebar. Pemberat diletakkan di atas selter agar tetap } \\
\text { berada di dasar wadah } \\
\text { Shelter made from raffia ropes with a length of } 20 \mathrm{~cm} \text { and a width of } 0.5 \mathrm{~cm} \text { as many as } 1,000 \\
\text { strands that were joined to one end and left extended and speared at the other end. Ballast is } \\
\text { placed on the shelter to remain at the bottom of the container }\end{array}$ \\
\hline
\end{tabular}

terhadap respons stres dan kinerja produksi. Apabila perlakuan berpengaruh signifikan maka dilanjutkan dengan uji Duncan untuk menentukan perlakuan yang terbaik. Apabila perlakuan tidak berpengaruh signifikan, maka dilakukan analisis secara deskriptif. Analisis deskriptif secara langsung juga digunakan untuk menjelaskan parameter kualitas air.

\section{HASIL DAN BAHASAN}

\section{Kualitas Air}

Budidaya lobster air tawar harus memperhatikan kondisi kualitas air yang sesuai dengan kemampuan hidupnya. Kualitas air yang diukur selama penelitian meliputi suhu, pH, oksigen terlarut, alkalinitas, kesadahan, TAN, nitrit, dan nitrat. Kisaran kualitas air selama masa penelitian dapat dilihat pada Tabel 2.

Seperti kegiatan budidaya pada umumnya, kualitas air menjadi bagian penting untuk diperhatikan karena pada kondisi lingkungan yang baik, maka biota budidaya pun akan hidup dan berkembang dengan baik. Kondisi suhu media pemeliharaan berkisar antara $25,97^{\circ} \mathrm{C}-28,90^{\circ} \mathrm{C}$; kondisi $\mathrm{pH}$ media pemeliharaan berkisar antara 7,09-8,08; konsentrasi oksigen terlarut media pemeliharaan berkisar antara 5,80-7,20 mg/L; alkalinitas media pemeliharaan berkisar antara 74,33$97,00 \mathrm{mg} \mathrm{CaCO} / \mathrm{L}$; kesadahan media pemeliharaan berkisar antara 53,77-78,10 mg $\mathrm{CaCO}_{3} / \mathrm{L}$; TAN media pemeliharaan berkisar antara 0,05-0,45 mg/L; nitrit media pemeliharaan berkisar antara 0,02-0,45 mg/L; dan nitrat pada media selama penelitian berkisar antara 0,22-1,31 mg/L. Secara umum kualitas air yang diukur selama penelitian masih berada dalam kisaran optimal bagi pemeliharaan lobster air tawar.

Kualitas air yang optimal disebabkan oleh metode pengelolaan kualitas air menggunakan sistem resirkulasi. Penggunaan sistem resirkulasi dapat menjaga kestabilan kualitas air dengan adanya sistem filtrasi di dalamnya. Kapas dakron dan pasir silika yang berperan sebagai filter fisik berfungsi dalam menyaring padatan tersuspensi dalam air berupa sisa pakan yang tidak termakan dan feses dari lobster air tawar. Zeolit yang berperan sebagai filter kimia berfungsi dalam penyerapan zat beracun seperti amonia (Supriyono et 
Tabel 2. Kisaran kualitas air setiap perlakuan selama penelitian dan kisaran optimal budidaya lobster air tawar

Table 2. Water quality range for each treatment during the research and the optimal range for freshwater crayfish cultivation

\begin{tabular}{|c|c|c|c|c|c|}
\hline \multirow{3}{*}{$\begin{array}{l}\text { Parameter kualitas air } \\
\text { Water quality parameters }\end{array}$} & \multicolumn{4}{|c|}{ Perlakuan (Treatments) } & \multirow{3}{*}{$\begin{array}{l}\text { Kisaran optimal } \\
\text { Optimal range }\end{array}$} \\
\hline & K & A & B & C & \\
\hline & $\begin{array}{l}\text { Tanpa selter } \\
\text { Without shelter }\end{array}$ & $\begin{array}{l}\text { Pipa PVC } \\
\text { PVC pipe }\end{array}$ & $\begin{array}{c}\text { Roster } \\
\text { Ventilation block }\end{array}$ & $\begin{array}{l}\text { Tali rafia } \\
\text { Raffia ropes }\end{array}$ & \\
\hline $\begin{array}{l}\text { Suhu } \\
\text { Temperature }\left({ }^{\circ} \mathrm{C}\right)\end{array}$ & $25.97-28.90$ & $25.97-28.90$ & $25.97-28.80$ & $25.97-28.83$ & $16-32 *$ \\
\hline $\mathrm{pH}$ & $7.09-8.06$ & $7.10-8.02$ & $7.10-8.02$ & $7.10-8.08$ & $6.5-9.0 * *$ \\
\hline $\begin{array}{l}\text { Oksigen terlarut } \\
\text { Dissolved oxygen (mg/L) }\end{array}$ & $5.80-7.10$ & $5.90-7.20$ & $5.90-7.13$ & $5.93-7.17$ & $>1^{* *}$ \\
\hline $\begin{array}{l}\text { Alkalinitas } \\
\text { Alkalinity }\left(\mathrm{mg} \mathrm{CaCO}_{3} / \mathrm{L}\right)\end{array}$ & $75.00-89.67$ & $74.33-90.67$ & $74.33-86.67$ & $75.67-97.00$ & $20-300$ ** \\
\hline $\begin{array}{l}\text { Kesadahan } \\
\left.\text { Hardness ( } \mathrm{mg} \mathrm{CaCO}_{3} / \mathrm{L}\right)\end{array}$ & $63.43-75.77$ & $53.77-67.43$ & $57.43-74.77$ & $60.77-78.10$ & $20-300$ ** \\
\hline TAN (mg/L) & $0.06-0.42$ & $0.06-0.34$ & $0.05-0.30$ & $0.06-0.45$ & $<0.5^{\text {** }}$ \\
\hline $\begin{array}{l}\text { Nitrit } \\
\text { Nitrite }(\mathrm{mg} / \mathrm{L})\end{array}$ & $0.02-0.36$ & $0.03-0.38$ & $0.06-0.45$ & $0.02-0.45$ & $<1^{* \text { *ak }}$ \\
\hline $\begin{array}{l}\text { Nitrat } \\
\text { Nitrate (mg/L) }\end{array}$ & $0.31-1.28$ & $0.22-1.10$ & $0.22-1.31$ & $0.24-1.16$ & $<50^{* * k}$ \\
\hline
\end{tabular}

Keterangan (Note): * Meade et al. (2002); ** Masser \& Rouse (1997); *** Manor et al. (2002)

al., 2007). Bioball yang berperan sebagai filter biologi berfungsi untuk media tempat pelekatan mikroba (bakteri nitrifikasi) yang dapat mendegradasi nitrogen ke dalam bentuk nitrat yang tidak beracun bagi ikan (Dewi \& Masithoh, 2013).

\section{Respons Stres}

Respons stres yang diamati pada penelitian ini meliputi glukosa dan protein total. Hasil pengukuran glukosa benih lobster air tawar semua perlakuan pada awal penelitian adalah sebesar $88,92 \mathrm{mg} / \mathrm{dL}$; sedangkan pada akhir penelitian dapat dilihat pada Gambar 1. Glukosa benih lobster air tawar terendah terdapat pada perlakuan selter tali rafia sebesar $101,00 \pm 17,35 \mathrm{mg} /$ $\mathrm{dL}$; sedangkan tertinggi terdapat pada perlakuan tanpa selter sebesar 137,33 $\pm 9,45 \mathrm{mg} / \mathrm{dL}$. Hasil yang didapat berdasarkan analisis ragam menunjukkan bahwa perlakuan tidak memberikan pengaruh signifikan terhadap glukosa benih lobster air tawar $(P>0,05)$.

Peningkatan glukosa pada lobster air tawar digunakan sebagai penanda sekunder dari respons stres (Jiang et al., 2013). Nilai glukosa benih lobster air tawar pada setiap perlakuan tidak berbeda nyata $(P>0,05)$, hal ini disebabkan lobster air tawar memiliki reputasi kuat dan tahan untuk menangani stres
(Edgerton et al., 2000). Namun, nilai glukosa yang tinggi pada perlakuan tanpa selter menunjukkan bahwa benih lobster air tawar mengalami kondisi stres paling tinggi dibanding perlakuan lain di mana semakin tinggi nilai glukosa mengindikasikan meningkatnya level stres. Benih lobster air tawar yang dipelihara tanpa menggunakan selter cenderung stres diduga karena benih lobster air tawar tidak memiliki tempat berlindung ketika melakukan aktivitasnya. Saat stres, glukosa diatur untuk mempertahankan homeostasi di dalam tubuh. Ketika tubuh membutuhkan energi yang lebih besar untuk mempertahankan homeostasi akibat stres, glukosa akan dihasilkan melalui mekanisme glikogenolisis dan glukoneogenesis, sehingga kadar glukosa mengalami peningkatan (Hastuti et al., 2004).

Selain glukosa, parameter respons stres lain yang diamati adalah protein total. Hasil pengukuran protein total benih lobster air tawar semua perlakuan pada awal penelitian adalah sebesar 4,23 g/dL; sedangkan pada akhir penelitian dapat dilihat pada Gambar 2. Protein total benih lobster air tawar terendah terdapat pada perlakuan selter tali rafia sebesar 5,00 $\pm 0,36 \mathrm{~g} / \mathrm{dL}$; sedangkan tertinggi terdapat pada perlakuan tanpa selter sebesar 6,93 \pm $9,45 \mathrm{~g} / \mathrm{dL}$. Hasil yang didapat berdasarkan analisis 


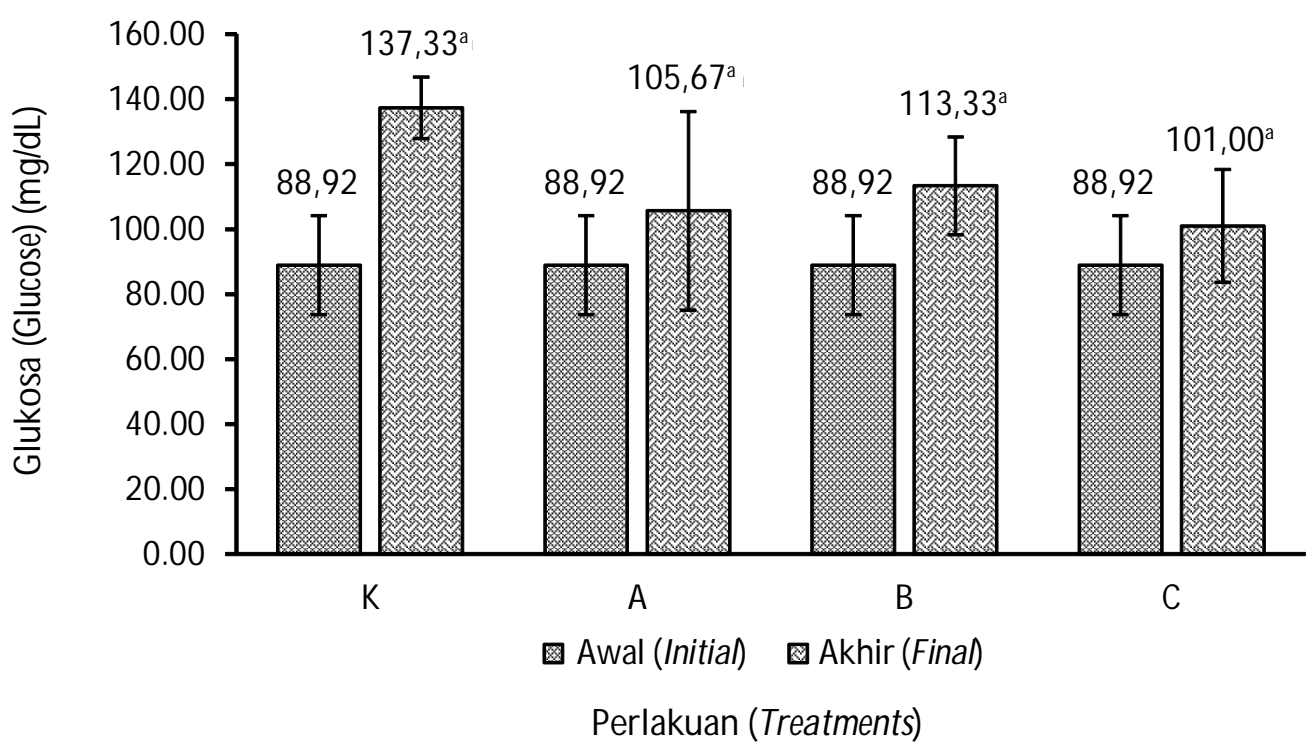

Gambar 1. Glukosa benih lobster air tawar pada perlakuan: K (tanpa selter), A (selter pipa PVC), B (selter roster), dan C (selter tali rafia). Huruf superskrip yang sama dalam grafik menunjukkan hasil yang tidak berbeda nyata $(P>0,05)$.

Figure 1. Freshwater crayfish seeds' glucose levels on treatment: $K$ (without shelter), $A$ (PVC pipe shelter), B (ventilation block shelter), and C (raffia ropes shelter). The same superscript letters on the graph show not significantly different results $(P>0.05)$.

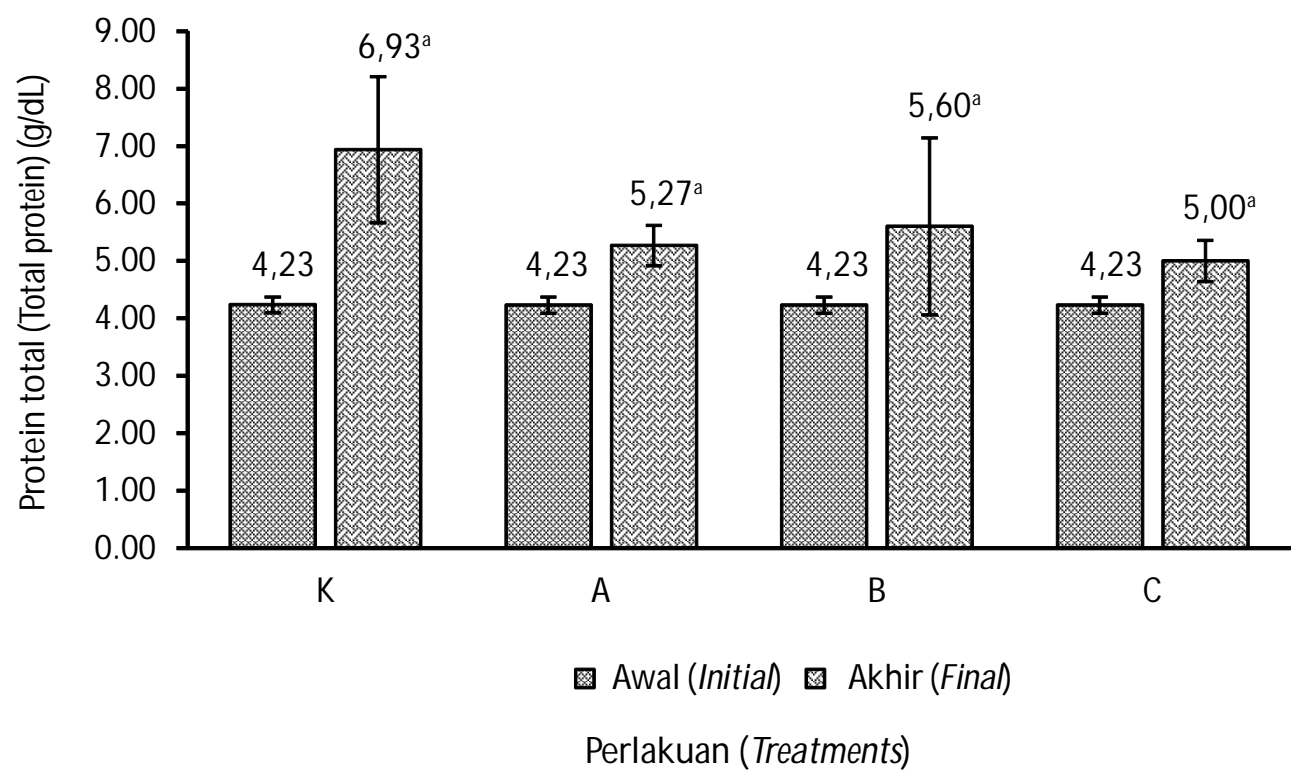

Gambar 2. Protein total benih lobster air tawar pada perlakuan: K (tanpa selter), A (selter pipa PVC), B (selter roster), dan C (selter tali rafia). Huruf superskrip yang sama dalam grafik menunjukkan hasil yang tidak berbeda nyata $(P>0,05)$.

Figure 2. Freshwater crayfish seeds' total protein on treatment: $K$ (without shelter), A (PVC pipe shelter), B (ventilation block shelter), and C (raffia ropes shelter). The same superscript letters on the graph show not significantly different results $(P>0.05)$. 
ragam menunjukkan bahwa perlakuan tidak memberikan pengaruh signifikan terhadap protein total benih lobster air tawar $(P>0,05)$.

Protein total berfungsi sebagai transportasi oksigen dalam tubuh, reproduksi, pertumbuhan, dan respons stres pada krustasea. Pengukuran protein total dapat memberikan informasi untuk mengidentifikasi kondisi krustasea (Lorenzon et al., 2011). Sama seperti nilai glukosa, nilai protein total benih lobster air tawar pada setiap perlakuan tidak berbeda nyata $(P>0,05)$. Nilai protein total tertinggi terdapat pada perlakuan tanpa selter yang menunjukkan bahwa benih lobster air tawar cenderung lebih stres, diduga karena benih lobster air tawar tidak memiliki tempat berlindung ketika melakukan aktivitasnya. Kondisi stres yang dialami benih lobster air tawar menyebabkan meningkatnya aktivitas metabolisme. Aktivitas metabolisme yang tinggi dapat menyebabkan kebutuhan oksigen meningkat. Hemolim pada krustasea terdiri atas sebagian besar hemosianin (> $60 \%$ dan sisanya terdiri atas protein yang meliputi koagulogen, apohemosianin, hormon, dan lipoprotein (Lorenzon et al., 2011). Hemosianin yang terdapat pada hemolim berperan sebagai alat transportasi oksigen dalam tubuh lobster air tawar. Hemosianin ketika dalam kondisi stres akan meningkat untuk memenuhi kebutuhan oksigen yang meningkat. Hemosianin pada beberapa spesies krustasea menyumbang lebih dari 93\%kadar protein total dalam hemolim (Sladkova \& Kholodkevich, 2011).

\section{Kinerja Produksi}

Kinerja produksi benih lobster air tawar dengan perlakuan penggunaan selter yang berbeda selama pemeliharaan 60 hari dapat dilihat pada Tabel 3. Pada Tabel 3 terlihat bahwa perlakuan memberikan pengaruh signifikan terhadap sintasan, Iaju pertumbuhan bobot spesifik, laju pertumbuhan panjang spesifik, rasio konversi pakan, dan biomassa total benih lobster air tawar $(P<0,05)$. Hasil penelitian menunjukkan bahwa ketika tidak ada selter yang disediakan pada pemeliharaan benih lobster air tawar, kinerja produksi sangat rendah, terutama karena penurunan sintasan.

Sintasan merupakan parameter penting dalam suatu kegiatan budidaya, karena menentukan jumlah produksi yang dihasilkan. Berdasarkan Tabel 3, sintasan masing-masing perlakuan berbeda nyata $(P<0,05)$ di mana perlakuan tanpa selter menjadi perlakuan dengan sintasan terendah. Hal tersebut menunjukkan bahwa selter sangat penting dalam pemeliharaan benih lobster air tawar. Dengan adanya selter, benih lobster air tawar memiliki tempat aman terhadap serangan kanibalisme yang akan mendukung sintasan. Pada perlakuan dengan selter, terdapat perbedaan nyata $(P<0,05)$ dari sintasan antara perlakuan selter tali rafia dengan perlakuan selter pipa PVC dan selter roster, namun tidak terdapat perbedaan nyata $(P>0,05)$ antara perlakuan selter pipa PVC dan selter roster. Hal ini diduga karena pada perlakuan dengan penggunaan selter tali rafia, benih lobster air tawar memiliki kesempatan yang lebih banyak untuk bersembunyi saat moulting pada untaian-untaian tali rafia yang menyebar di media pemeliharaan. Tali rafia mampu memisahkan banyak individu sehingga dapat mengurangi kanibalisme dengan cara meminimalkan kontak antarbenih lobster air tawar.

Bobot rata-rata benih lobster air tawar pada awal penelitian berkisar antara 0,60 $\pm 0,09-0,64 \pm 0,02$ g. Pengamatan terhadap pertumbuhan bobot setiap periode pengamatan (10 hari) dapat dilihat pada Gambar 3. Bobot rata-rata benih lobster air tawar pada semua perlakuan meningkat seiring dengan lamanya waktu pemeliharaan. Bobot rata-rata benih lobster air tawar mengalami peningkatan pada setiap perlakuan dari awal hingga akhir pemeliharaan. Peningkatan ini menunjukkan pertumbuhan benih lobster air tawar. Secara garis besar perlakuan selter tali rafia memberikan hasil pada pertumbuhan bobot rata-rata benih lobster air tawar yang paling baik apabila dibandingkan dengan perlakuan lainnya. Hal ini dikarenakan, perlakuan selter tali rafia memberikan respons stres yang lebih rendah dari perlakuan lainnya, sehingga energi yang digunakan untuk homeostasi selama stres dimanfaatkan untuk pertumbuhan.

Panjang total rata-rata benih lobster air tawar pada awal penelitian berkisar antara sebesar $2,55 \pm 0,06-$ $2,61 \pm 0,03 \mathrm{~cm}$. Pengamatan terhadap pertumbuhan panjang total setiap periode pengamatan (10 hari) dapat dilihat pada Gambar 4. Panjang total rata-rata benih lobster air tawar pada semua perlakuan meningkat seiring dengan lamanya waktu pemeliharaan. Selaras dengan bobot rata-rata, panjang total rata-rata benih lobster air tawar juga mengalami peningkatan pada setiap perlakuan dari awal hingga akhir pemeliharaan. Peningkatan ini menunjukkan pertumbuhan benih lobster air tawar. Pada pertumbuhan panjang total rata-rata benih lobster air tawar, selter tali rafia memberikan hasil yang paling baik apabila dibandingkan dengan perlakuan lainnya. Hal ini dikarenakan, perlakuan selter tali rafia memberikan respons stres yang lebih rendah dari perlakuan lainnya, sehingga energi yang digunakan untuk homeostasi selama stres dimanfaatkan untuk pertumbuhan. 
Tabel 3. Kinerja produksi benih lobster air tawar pada setiap perlakuan

Table 3. Production performance of freshwater crayfish seeds in each treatments

\begin{tabular}{|c|c|c|c|c|}
\hline \multirow{3}{*}{$\begin{array}{c}\text { Kinerja produksi } \\
\text { Production perform ance }\end{array}$} & \multicolumn{4}{|c|}{ Perlakuan (Treatments) } \\
\hline & K & A & B & C \\
\hline & $\begin{array}{c}\text { Tanpa selter } \\
\text { Without shelter }\end{array}$ & $\begin{array}{l}\text { Pipa PVC } \\
\text { PVC pipe }\end{array}$ & $\begin{array}{c}\text { Roster } \\
\text { Ventilation block }\end{array}$ & $\begin{array}{l}\text { Tali rafia } \\
\text { Raffia ropes }\end{array}$ \\
\hline $\begin{array}{l}\text { Sintasan } \\
\text { Survivat rate }(\%)\end{array}$ & $31.11 \pm 3.85^{\mathrm{a}}$ & $60.00 \pm 6.67^{b}$ & $62.22 \pm 3.85^{b}$ & $86.67 \pm 0.00^{c}$ \\
\hline $\begin{array}{l}\text { Bobot awal } \\
\text { Initial weight (g) }\end{array}$ & $0.64 \pm 0.02$ & $0.63 \pm 0.05$ & $0.60 \pm 0.04$ & $0.60 \pm 0.09$ \\
\hline $\begin{array}{l}\text { Bobot akhir } \\
\text { Final weight (g) }\end{array}$ & $2.86 \pm 0.09$ & $3.36 \pm 0.06$ & $3.37 \pm 0.01$ & $3.46 \pm 0.08$ \\
\hline $\begin{array}{l}\text { Panjang total awal } \\
\text { Initial total length }(\mathrm{cm})\end{array}$ & $2.55 \pm 0.03$ & $2.61 \pm 0.03$ & $2.59 \pm 0.09$ & $2.55 \pm 0.06$ \\
\hline $\begin{array}{l}\text { Panjang total akhir } \\
\text { Final total length }(\mathrm{cm})\end{array}$ & $4.47 \pm 0.02$ & $4.83 \pm 0.06$ & $4.90 \pm 0.06$ & $5.08 \pm 0.12$ \\
\hline $\begin{array}{l}\text { LPBS (\%/hari) } \\
\text { SW GR (\%days) }\end{array}$ & $2.49 \pm 0.01^{\mathrm{a}}$ & $2.78 \pm 0.11^{b}$ & $2.87 \pm 0.09^{b}$ & $2.92 \pm 0.21^{b}$ \\
\hline $\begin{array}{l}\text { LPPS (\%hari) } \\
\text { SLGR (\%ddays) }\end{array}$ & $0.93 \pm 0.01^{\mathrm{a}}$ & $1.03 \pm 0.03^{\mathrm{ab}}$ & $1.06 \pm 0.07^{b c}$ & $1.15 \pm 0.08^{c}$ \\
\hline $\begin{array}{l}\text { Rasio konversi pakan (RKP) } \\
\text { Feed conversion ratio (FCR) }\end{array}$ & $3.64 \pm 0.08^{b}$ & $3.05 \pm 0.05^{\mathrm{a}}$ & $2.98 \pm 0.05^{\mathrm{a}}$ & $2.97 \pm 0.05^{a}$ \\
\hline $\begin{array}{l}\text { Biomassa total } \\
\text { Total biomass }(\mathrm{g})\end{array}$ & $13.36 \pm 1.99^{a}$ & $30.17 \pm 2.88^{b}$ & $31.45 \pm 2.06^{b}$ & $45.02 \pm 1.10^{c}$ \\
\hline $\begin{array}{l}\text { konversi pakan. } \\
\text { berbeda nyata ( } P\end{array}$ & superskrip yano & $\begin{array}{l}\text { LPPS = laju pert } \\
\text { rbeda pada bari }\end{array}$ & g sama meni & $\begin{array}{l}\text { ifik; RKP= rasio } \\
\text { tan hasil yang }\end{array}$ \\
\hline $\begin{array}{l}\text { SWGR }=\text { specific } W \\
\text { ratio. The different }\end{array}$ & $\begin{array}{l}\text { growth rate; SL } \\
\text { arscript letters or }\end{array}$ & $\begin{array}{l}R=\text { specific length } \\
\text { he same row show }\end{array}$ & $\begin{array}{l}\text { wth rate; } F C R=f \in \\
\text { gnificantly different }\end{array}$ & $\begin{array}{l}\text { ed conversion } \\
\text { results }(P<0.05)\end{array}$ \\
\hline
\end{tabular}

Pertumbuhan merupakan perubahan ukuran biota budidaya baik dalam bobot, panjang maupun volume selama periode waktu tertentu yang disebabkan oleh perubahan jaringan tubuh biota budidaya sehingga menyebabkan penambahan bobot atau panjang ikan (Effendie, 1997). Pertumbuhan bobot dan panjang badan pada krustasea terjadi secara berkala setelah moulting (Chang et al., 2012). Beberapa parameter pertumbuhan yang diamati pada penelitian ini antara lain laju pertumbuhan bobot spesifik dan Iaju pertumbuhan panjang spesifik. Kedua parameter tersebut memiliki korelasi positif. Laju pertumbuhan bobot spesifik dan laju pertumbuhan panjang spesifik tertinggi berdasarkan Tabel 3 terdapat pada perlakuan selter tali rafia dan terendah pada perlakuan tanpa selter.

Rasio konversi pakan merupakan rasio kebutuhan jumlah pakan untuk menghasilkan satu kilogram bo bot biota budidaya (NRC, 1977). Perlakuan selter tali rafia memiliki rasio konversi pakan paling rendah. Rasio konversi pakan yang rendah menunjukkan bahwa energi pakan yang diberikan dapat dimanfaatkan secara efisien sehingga jumlah pakan yang dibutuhkan untuk pertumbuhan menjadi lebih sedikit dibanding perlakuan lainnya. Rendahnya rasio konversi pakan juga mengindikasikan penggunaan energi oleh benih lobster air tawar untuk aktivitas hidup dan yang hilang melalui jalur ekskresi relatif kecil sehingga benih lobster air tawar memiliki kelebihan energi yang dapat digunakan untuk pertumbuhan. Semakin rendah rasio konversi pakan maka semakin efisien pula penyerapan pakan yang kemudian diubah menjadi daging (bobot). Hal tersebut sejalan dengan respons stres yang lebih rendah pada perlakuan selter tali rafia, sehingga energi yang digunakan untuk homeostasi selama stres lebih rendah dan pemanfaatan energi yang berasal dari pakan lebih optimal untuk melakukan pertumbuhan. 


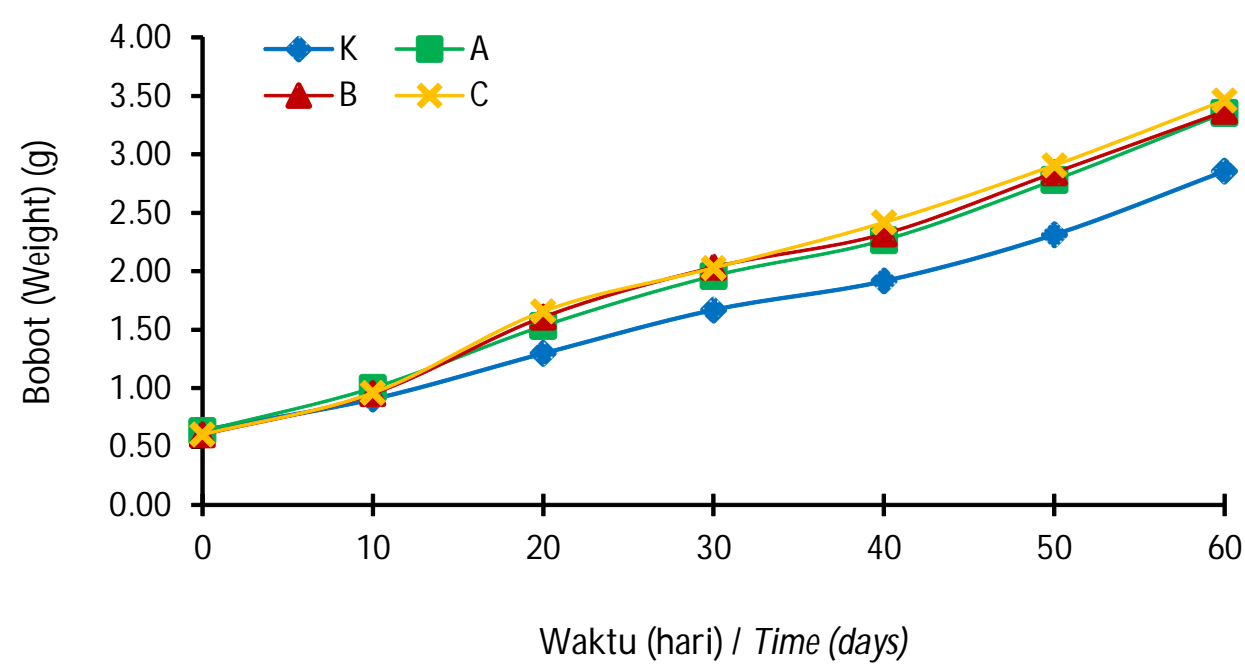

Gambar 3. Pertumbuhan bobot benih lobster air tawar selama penelitian pada perlakuan: K (tanpa selter), A (selter pipa PVC), B (selter roster), dan C (selter tali rafia).

Figure 3. Weight growth of freshwater crayfish seeds in treatment: $\mathrm{K}$ (without shelter), A (PVC pipe shelter), B (ventilation block shelter), and C (raffia ropes shelter).

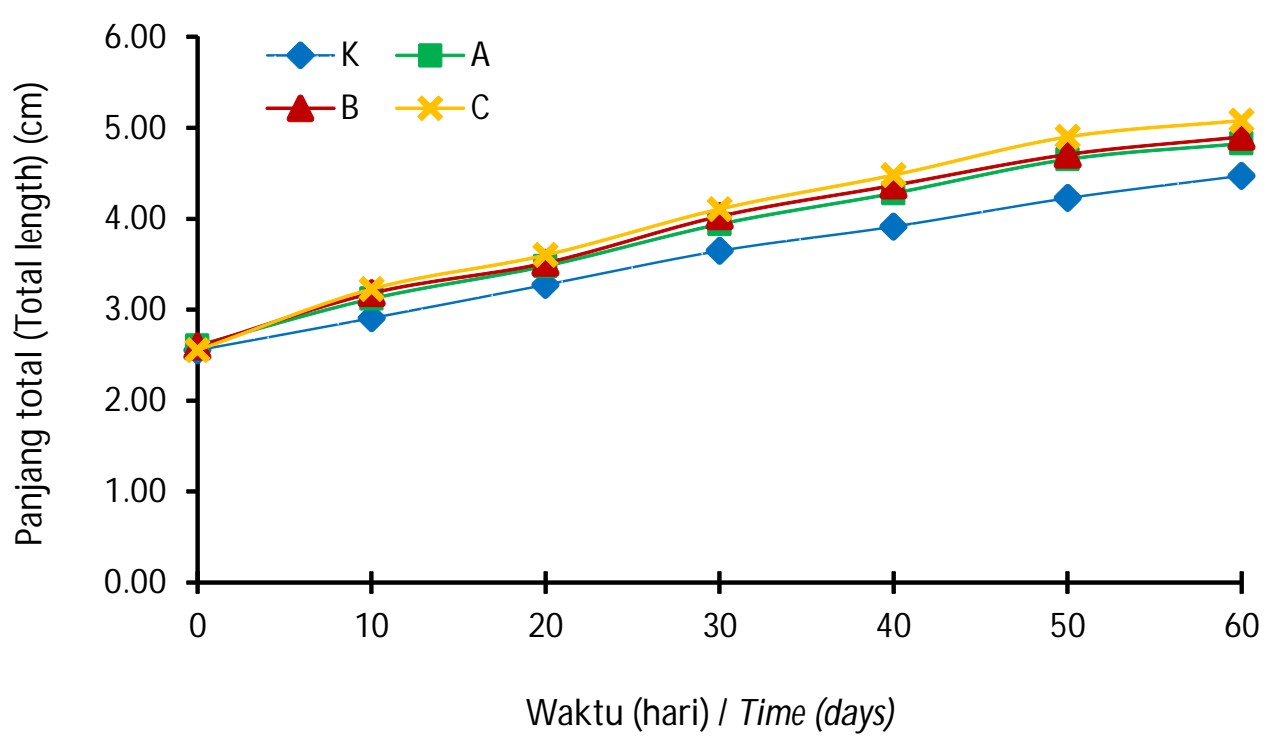

Gambar 4. Pertumbuhan bobot benih lobster air tawar selama penelitian pada perlakuan: K (tanpa selter), A (selter pipa PVC), B (selter roster), dan C (selter tali rafia).

Figure 4. Total length growth of freshwater crayfish seeds in treatment: $\mathrm{K}$ (without shelter), A (PVC pipe shelter), B (ventilation block shelter), and C (raffia ropes shelter).

Biomassa total pada kegiatan akuakultur memegang peranan penting pada keuntungan yang diperoleh dalam kegiatan akuakultur. Pertumbuhan dan sintasan biota budidaya menjadi faktor penentu tingginya biomassa total yang diperoleh. Biomassa total dikatakan maksimal jika jumlah dan pertumbuhan biota budidaya yang dipelihara tinggi. Jika jumlah biota budidaya tinggi tetapi pertumbuhan rendah, maka biomassa total yang didapat tidak maksimal. Pertumbuhan tinggi tetapi jumlah biota budidaya 
rendah, maka biomassa total yang didapat juga tidak maksimal. Biomassa total tertinggi terdapat pada perlakuan selter tali rafia dan terendah terdapat pada perlakuan tanpa selter. Biomassa total pada perlakuan selter tali rafia berbeda nyata $(P<0,05)$ dengan perlakuan lainnya. Hal tersebut selaras dengan sintasan dan pertumbuhan yang tinggi pada perlakuan selter tali rafia.

\section{KESIMPULAN}

Penggunaan selter dapat menekan tingkat stres dan memaksimalkan kinerja produksi pendederan lobster air tawar. Selter tali rafia merupakan selter yang terbaik dilihat dari respons stres yang paling rendah dan kinerja produksi yang paling tinggi.

\section{UCAPAN TERIMA KASIH}

Ucapan terima kasih disampaikan kepada Sdr. Sepanya Kristina Sihombing atas pendampingannya selama proses penelitian. Terima kasih juga disampaikan kepada teknisi Laboratorium Kolam Percobaan Babakan FPIK IPB, Laboratorium Lingkungan FPIK IPB, dan Laboratorium Patologi PSSP IPB atas bantuannya dalam penelitian ini.

\section{DAFTAR ACUAN}

Adiyana, K., Supriyono, E., Junior, M.Z., \& Thesiana, L. (2014). Aplikasi teknologi selter terhadap respons stres dan kelangsungan hidup pada pendederan lobster pasir Panulirus homarus. Jurnal Kelautan Nasional, 9(1), 1-9.

Chang, Y.J., Sun, C.L., Chen, Y., \& Yeh, S.Z. (2012). Modelling the growth of crustacean species. Reviews in Fish Biology and Fisheries, 22, 157-187.

Dewi, Y.S. \& Masithoh, M. (2013). Efektivitas teknik biofiltrasi dengan media bio-ball terhadap penurunan kadar nitrogen total. Jurnal Limit's, 9(1), 45-53.

Edgerton, B.F., Webb, R., Anderson, I.G., \& Kulpa, E.C. (2000). Description of a presumptive hepatopancreatic reovirus and aputative gill parvovirus in the freshwater crayfish Cherax quadricarinatus. Disease of Aquatic Organisms, 41, 83-90.

Effendie, M.I. (1997). Biologi perikanan. Yogyakarta: Yayasan Pustaka Nusantara, $163 \mathrm{hlm}$.

Food and Agriculture Organization of United Nation [FAO]. (2016). The State of World Fisheries and Aquaculture 2016. Contributing to Food Security and Nutrition for All. Rome: FAO, $190 \mathrm{pp}$.

García-Ulloa, G.M., Pérez-Moreno, M.R., RodríguezGonzález, D., Gallo-García, M.C., Ponce-Palafox, J.T., Rodríguez-González, H., \& Góngora-Gómez,
A.M. (2012). Stocking density for nursery production of redclaw crayfish Cherax quadricarinatus in a Recirculating System. Journal of Applied Aquaculture, 24, 8-15.

Hastuti, S., Supriyono, E., Mokoginta, I., \& Subandiyono. (2003). Respons glukosa darah ikan gurami Osphronemus gouramy LAC terhadap stres akibat perubahan suhu lingkungan. Jurnal Akuakultur Indonesia, 2(2), 73-77.

Jiang, Q.C., Dilixiati, A., Zhang, C., Liu, X.Z., Huang, W.T., Wang, L.L.L.Q., \& Yang, J.X. (2013). Metabolic and antioxidant responses in juveniles of Cherax quadricarinatus under accute cadmium stress. Journal of Crustacean Biology, 33(4), 552556.

Jones, C.M. (1995). Production of juvenile redclaw crayfish, Cherax quadricarinatus (von Martens) (Decapoda, Parastacidae) III. Managed pond production trials. Aquaculture, 138, 247-255.

Jones, C.M., McPhee, C.P., \& Ruscoe, I.M. (2000). A review of genetic improvement in growth rate in redclaw crayfish Cherax quadricarinatus (Decapoda: Parastacidae). Aquaculture Research, 31, 61-67.

Jones, C.M. \& Ruscoe, I.M. (2001). Assessment of five shelter types in the production of redclaw crayfish Cherax quadricarinatus (decapoda: parastacidae) under earthen pond conditions. World Aquaculture Society, 32(1), 41-52.

Karplus, I., Barki, A., Levi, T., Hulata, G., \& Harpaz, S. (1995). Effects of kinship and shelter on growth and survival of juvenil Australian redclaw crayfish (Cherax quadricarinatus). Freshwater Crayfish, 10, 498-505.

Kurniasih, T. (2008). Lobster air tawar (Parastacidae: Cherax), aspek biologi, habitat, penyebaran, dan potensi pengembangannya. M edia Akuakultur, 3(1), 31-35.

Lorenzon, S., Martinis, M., \& Ferrero, E.A. (2011). Ecological relevance of hemolymph total protein concentration in seven unrelated crustacean species from different habitats measured predictively by a density-salinity refractometer. Journal Marine Biology, p. 1-7.

Lukito, A. \& Prayugo, S. (2007). Panduan lengkap lobster air tawar. Jakarta: Penebar Swadaya, $291 \mathrm{hlm}$.

Manor, R., Segev, R., Leibovitz, M.P., Aûalo, E.D., \& Sagi, A. (2002). Intensiûcation of redclaw crayûsh Cherax quadricarinatus culture II. Growout in a separate cell system. Aquacultural Engineering, 26, 263-276.

Masser, M.P. \& Rouse, D.B. (1997). Australian red claw crayfish. Mississipi: Southern Regional Aquaculture Center Publication, 244 pp. 
Meade, M.E., Doeller, J.E., Kraus, D.W., \& Watts, S.A. (2002). Effects of temperature and salinity on weight gain, oxygen consumption rate, and growth efficiency in juvenile red-claw crayfish Cherax quadricarinatus. World Aquaculture Society, 33(2), 188-198.

Munasinghe, D., Burridge, C., \& Austin, C. (2004). Molecular phylogeny and zoogeography of the freshwater crayfish genus Cherax Erichson (Decapoda: Parastacidae) in Australia. Biological Journal of the Linnean Society, 81(81), 553-563.

National Research Council [NRC]. (1977). Nutrient requirement of warmwater fishes and shelfishes revised edition. Washington: National Academy Press, $102 \mathrm{pp}$.

Olszewski, P. (1980). A salute to the humble yabby. Sydney: Angus and Robertson, $150 \mathrm{pp}$.

Parnes, S. \& Sagi, A. (2002). Intensification of redclaw crayfish Cherax quadricarinatus culture I. Hatchery and nursery system. Aquacultural Engineering, 26, 251-262.

Rodriguez-Canto, A., Arredondo-Figueroa, J., PoncePalafox, J., \& Rouse, D.B. (2002). Growth characteristics of the Australian redclaw crayfish, Cherax quadricarinatus, cultured in an indoor recirculating system. Aquaculture, 12(3), 59-64.

Sladkova, S.V. \& Kholodkevich, S.V. (2011). Total protein in hemolymph of crawfish Pontastacus leptodactylus as a parameter of the functional state of animals and a biomarker of quality of habitat. Journal of Evolutionary Biochemistry and Physiology, 47, 160-167.

Supriyono, E., Supendi, A., \& Nirmala, K. (2007). Pemanfaatan zeolit dan karbon aktif pada sistem pengepakan ikan corydoras Corydoras aenus. Jurnal Akuakultur Indonesia, 6, 135-145.

Timmons, M.B. \& Losordo, T.M. (1994). Aquaculture water reuse system: Engineering design and management. Amsterdam: Elsevier Science, 348 pp.

Verhoef, G.D. \& Austin, C.M. (1999). Combined effects of temperature and density on the growth and survival of juveniles of the Australian freshwater crayûsh, Cherax destructor Clark, Part 1. Aquaculture, 170, 37-47.

Woodward, C.C. \& Strange, R.J. (1987). Physiological stress responses in wild and hatchery - reared rainbow trout. Transactions of the American Fisheries Society, 116, 574-579. 